\title{
The International Financial Crisis and China: Impacts, Challenges, and Policies*
}

\author{
Changzheng Dai** and Xuan Qiao***
}

\begin{abstract}
The Chinese economy has been severely affected by the global financial crisis triggered by the United States. China's imports and exports have been shrinking, and many enterprises closely related to international trade have been shut down. China has also been embarrassed by its US\$2.1 trillion foreign exchange reserve and anxious to know how to manage it effectively. As the economic situation has become increasingly gloomy and uncertain, social problems such as layoffs have increased, and social security and social stability have inevitably appeared to worsen. This has caught the attention of the authorities. Public policies have to be adjusted and new policies established, and effective countermeasures have to be planned, so as to enable China to survive the crisis. Fiscal, monetary, industrial, and social policies have been initiated and are expected to work. Though their success is difficult to estimate, those measures nevertheless have manifested the determination of the Chinese government to conquer the current difficulties, as it has promised the people.
\end{abstract}

Keywords: financial crisis, impacts on China, policy measures

* The research is supported by the 3rd period of fund of 211 program of University of International Business and Economics, Program Code: 73300025. Dr. Dai would like to thank Professor Yong-duck Jung for his invaluable academic and personal supports, and also the discussants and commentators at the International Conference on the Occasion of the 18th Anniversary of Founding the Korea Institute of Public Administration (KIPA). The authors thank the anonymous referees of KJPS for their academic evaluations and constructive suggestions for revising.

** Changzheng Dai is Dean and Professor at the School of International Relations, University of International Business and Economics, Beijing. At present, his main research and teaching include Chinese politics, and administrative theories and practice. Address: No. 10 East Huixin Street, Chaoyang District, Beijing, China, 100029. Email: daicz@ 126.com.

*** Xuan Qiao is Assistant Professor at the School of International Relations, University of International Business and Economics, Beijing. Dr. Qiao's main research fields include Chinese politics and diplomacy strategy. Address: No. 10 East Huixin Street, Chaoyang District, Beijing, China, 100029. Email: kaneqx_7@ @otmail.com.

Manuscript received February 8, 2010; out for review March 7, 2010; review completed April 12, 2010; accepted April 15, 2010.

The Korean Journal of Policy Studies, Vol. 25, No. 1, 109-122 (2010)

(C) 2010 by the GSPA, Seoul National University 


\section{INTRODUCTION}

The subprime mortgage crisis broke out with New Century Financial Corporation's application for bankruptcy protection in the United States in April 2007. It was the second largest American subprime mortgage institution that had proclaimed a deficit in the fourth quarter of 2006. The crisis then spread to the securities markets. Many institutional investors suffered great losses, and some went bankrupt, especially in the second half of 2008. The physical economy also suffered as a result of credit reduction.

The crisis then spread to the global economy. It became an international financial crisis for three reasons: (1) American dollars, freed from regulation, had not been able to guide the international monetary system since the Bretton Woods system fell apart in the early 1970s; (2) the American savings rate was so low that the high U.S. consumption level was sustained by borrowing from the whole world; (3) the U.S. Federal Reserve has always adopted an expansionary monetary policy and practiced weak financial supervision to support the prosperity of the American capital market (Wu 2009, 13).

Many economies have suffered from this crisis. Recovery attempts have included the government rescuing the market, lower interest rates, and economic stimulus plans. For example, the U.S. government has invested hundreds of billions dollars to rescue the domestic economy, and the South Korean government says it will continue to implement expansionary macroeconomic policies to boost the economy in 2010.

Much like in other countries, China's economy has been affected by the global economic downturn. China has become deeply involved in the process of globalization after 30 years of reform and opening to the world. Thus, the global crisis has had a profound impact on China's economy. It has caused an economic slowdown and worsened domestic employment, affecting social security and stability. The Chinese government has taken active measures to deal with the crisis, promote faster economic growth, and maintain social stability and development.

\section{IMPACT OF THE FINANCIAL CRISIS ON CHINA}

\section{China's Economic Slowdown}

The global financial crisis continues to spread and worsen, demand continues to shrink on international markets, the external economic environment has become more serious, and uncertainties have increased significantly. The gloomy global economy, particularly the economic slowdown in the United States, has created a negative 
impact on China's exports. Decline in U.S. import demand has slowed China's export growth. High U.S. government spending to rescue the market will cause depreciation of the dollar, which would have a negative impact on China's economy. When the dollar falls, it will result in a faster appreciation of the renminbi (RMB), which will affect China's exports.

In order to stimulate the domestic economy and increase employment, the U.S. government may also increase trade protection. Past statistics show that a 1 percent reduction in U.S. economic growth is likely to lead to a more than 5 percent decline in China's exports. The U.S. recession has led to shrinking market demand, more intense market competition, and declining product prices, and has caused many Chinese export enterprises to stop production because of sharply decreasing orders and increasing export difficulties. At the 2009 East China Fair, business declined by 39 percent from the previous year. And at the 105th Canton Fair, the number of foreign investors was visibly reduced and business transactions also declined, showing that the global economic recession and financial crisis have seriously affected China's economy. According to official statistics, 2009 Chinese imports and exports totaled US\$2.2 trillion, of which exports made up US\$1.2 trillion and imports US\$1.0 trillion-down 13.9 percent in total comparing with the same period in 2008 (Xinhua News Agency 2010,5).

The risk to Chinese foreign exchange reserves management and foreign investment has increased. At present, the amount of Chinese foreign exchange reserves has climbed to more than US\$2.1 trillion, the highest in the world (State Administration of Foreign Exchange 2009). After the outbreak of the financial crisis, the exchange rate risk has appeared quickly in the aspect of the foreign exchange reserves. Because of financial globalization, managing such huge foreign exchange reserves and ensuring that their value is preserved is difficult, since China lacks successful experience in overseas investment.

With the appreciation of the RMB, China has invested a significant amount of its dollar reserves in low-risk U.S. treasury bonds, but has suffered exchange rate losses. In addition, the deepening financial crisis, under the U.S. bailout plan and the reduction of the federal benchmark interest rate, will inevitably lead to a decline in U.S. bond yields. As the largest holder of U.S. treasury bonds, China will face the impact of reduced assets. The crisis has also caused turbulence in global financial markets, so that China's foreign exchange reserves have suffered huge losses in overseas investments.

Compared with the treasury bonds, corporate bonds and stocks have higher yields but also higher risks. In recent years, China's financial institutions and the newly established China investment corporations have invested in corporate bonds and stocks and suffered huge losses. By the end of 2008, China had surpassed Japan and 
the United Kingdom to become the United States' largest creditor. China currently holds about US\$889 billion in U.S. treasury bonds. Such huge holdings, given the current global financial market turbulence, will further increase the risk of Chinese foreign investment.

China's financial market is being challenged. China's financial regulatory authorities have strictly controlled the business of overseas credit derivatives, so Chinese financial institutions have held a smaller amount of subordinated bonds, and have experienced relatively small losses compared with those of the United States and European countries. Because of strict Chinese capital controls, China's capital markets and international capital markets are separate, so the domestic capital market being hit by the crisis is also smaller. Therefore, the direct impact of the crisis on Chinese financial markets is limited and largely psychological. The Chinese stock market fell by 60 percent, far exceeding the U.S. and European market adjustments, showing the panic of Chinese investors facing these external shocks.

Some of China's large commercial banks have suffered losses in the crisis, though most of them have declared no loss or only a small loss. But with the continued deepening of the crisis and further declines in financial capital prices in developed countries, losses by some domestic banks can not be avoided. If these losses are within the banks' tolerance range, the effects could be acceptable; but if the losses are too large, these banks would have to tighten credit in order to maintain an adequate capital ratio, which would create difficulties for corporate lending.

\section{Impact of Severe Domestic Unemployment on Social Security and Stability}

Reductions in the demand for labor and in wages are a direct consequence of the economic crisis. Affected by the international economic crisis, many Chinese enterprises have performed inefficiently and become trapped in a poor business situation. Theoretically, in the financial crisis, a large number of labor-intensive enterprises, small and medium enterprises, and companies with poor ability to resist risks will face bankruptcy, liquidation, and restructuring. Some companies have begun to reduce employment, and employees are facing severe problems. Generally speaking, every 1 percent fluctuation in China's exports will affect the jobs of 180,000 to 200,000 people in China ( $\mathrm{Ru}, \mathrm{Lu}$, and $\mathrm{Li} 2008,134)$. Since the financial crisis began, a large number of export-oriented small and medium-size enterprises in Guangdong, Jiangsu, and other coastal areas have closed, and unemployment has risen.

From the beginning of the financial crisis to early 2009, about 20 million migrant workers, accounting for 15.3 percent of the total, returned home because of losing their jobs or not finding work (Chen 2009, 18). Meanwhile, China also faces enor- 
mous pressure on employment of college students. Official statistics show that in 2009, 6.1 million new college graduates needed jobs, in addition to 1 million college graduates who had not found jobs the year before, for a total of about 7.1 million people seeking work, the highest number in history. And the employment pressure would further increase in 2010. (Xinhua News Agency 2009c, 18)

This severe economic situation is affecting social security and stability. A financial crisis usually causes economic slowdown and rising unemployment, which often leads to a crime increase, or even confrontation between different economic classes, thus affecting a country's social security and stability. Some experts believe that Chinese conflicts that have been building for a long time have been exposed because of the economic slowdown, with hidden conflicts becoming more visible and visible conflicts more severe. Since the financial crisis, many manufacturing enterprises have encountered difficulties, and they have often reduced workers' wages to transfer business risks, resulting in a sharp increase in labor disputes. For example, in Dongguan City, Guangdong Province, some unexpected events have been triggered by severe labor disputes-including mobs blocking traffic (about 40 percent), collective petitions (22 percent), and strikes (8 percent) (Mao and Yang 2009, 6).

\section{CHINA'S COUNTERMEASURES}

As Chinese Premier Wen Jiabao said, "In the face of economic difficulty, confidence is more valuable than gold and currency." (Wen 2009b, 1) The Chinese government has developed a package of measures to deal with the financial crisis, involving fiscal policy, monetary policy, industrial policy, social policy, and strengthening international cooperation.

\section{Fiscal Policy}

Many countries are adopting fiscal policies aimed at expanding domestic demand to compensate for reductions in external demand because of the financial crisis. The Chinese people sent a strong signal to the government regarding the importance of sustaining growth, boosting domestic demand, and ensuring people's well-being.

Since 2008, China's main fiscal policies have included the following:

1. Expanding public investment and vigorously promoting consumer demand: The government proposed an economic stimulus plan of 4 trillion RMB for 2009-2010. Because financial resources can promote economic growth, the 
government has also promoted consumption in several ways, including providing 45 billion RMB in subsidies for rural residents to purchase home appliances and motor vehicles (Wen 2010, 1).

2. Promoting tax reform by adjusting the taxation system to reduce the burden on businesses and residents: The government has introduced a tax cut of about 500 billion RMB and improved export rebates (Wen 2009a, 3), which can encourage enterprises to expand investment and enhance people's consumption capacity.

3. Increasing the amount of financial assistance to low-income groups: The use of fiscal policy to adjust the national income distribution pattern has focused especially on increasing low-income urban and rural income and spending power.

4. Optimizing the structure of financial expenditures to safeguard and improve people's livelihoods: General expenses have been strictly controlled, and support for agriculture, education, employment, housing, health care, social security, and other areas of people's livelihoods has been increased. According to the rules of social development and the different characteristics of public services, effective long-term mechanisms of financial protection have been established gradually to improve people's livelihoods.

The government has made reversing the downward trend in economic growth the primary goal of macro control, and has made boosting domestic demand a long-term strategic principle and a basic point of departure for stimulating economic growth. China works to increase effective demand and gives full play to the leading role of domestic demand, particularly consumer demand, in driving economic growth. This macro control is expected not only to manage the free market economy effectively, but also to enhance people's confidence in economic development. In 1998, China announced the implementation of a proactive fiscal policy that played a very important role in overcoming the 1997-98 Asian financial crisis and stabilizing China's economy. Measures included increasing long-term construction treasury bonds and supporting major infrastructure construction.

Today, China will again increase fiscal expenditures and expand the investment scale. These forceful policies and their direct effects are intended to stimulate the economy, promote consumption to maintain stable and rapid economic development, and avoid big ups and downs in the economy. The central goal of this proactive fiscal policy and loose monetary policy is to promote steady and relatively fast growth — and to lay a solid foundation to protect people's livelihoods. These steps reflect the expansion of investment as well as the optimization of the economic structure, which it is hoped will solve the current problems and sustain long-term development.

In 2009, the central government's public investment was 924.3 billion RMB, 503.8 
billion RMB more than in the previous year's budget. Fixed asset investment increased 30.1 percent nationwide. China further improved the investment structure. Rapid investment growth effectively compensated for the shortfall created by shrinking external demand, strengthened weak links, and laid a solid foundation for longterm economic and social development (Wen 2010, 1). In accordance with the International Monetary Fund's (IMF's) estimates, the size of China's active fiscal policy will account for 4.4 percent of GDP during 2008-2010, placing China in the forefront of the world's great powers.

\section{Monetary Policy}

At the same time, the Chinese government has followed a moderately easy monetary policy and created a loose monetary flow environment, primarily in the following ways:

1. It has paid more attention to changes in major international currency exchange rates and further improved the RMB exchange rate mechanism, enhancing exchange rate flexibility and keeping the RMB exchange rate stable.

2. It has used several methods to expand agriculture credit, such as adopting a lower reserve ratio, instituting a pilot reform of rural credit cooperatives, providing financial support, and increasing and regulating relending quotas. China will continue to deepen reform of rural credit cooperatives and vigorously develop village banks, small loan companies, rural credit union funds, and other new rural financial institutions, strengthening the rural financial infrastructure and improving rural financial services.

3. It has increased financial support for small enterprise development. China has strengthened guidance to the financial institutions and encouraged innovation in small business credit products and trade financing instruments, constructed a multilevel small business financing system, expanded the direct financing channels for small businesses, regulated and guided private capital into the small business financing market, and accelerated the construction of a credit system and guarantee system to improve the financing environment for small businesses.

4. It is working to improve the social credit environment and continues to deepen financial reform and actively maintain financial security and stability.

On the one hand, China should pay great attention to developments in the international financial crisis and undertake in-depth study of the approaches and mechanisms of financial crisis management. On the other hand, in accordance with the requirements of modern commercial banks, China should continue to promote reform of the 
domestic commercial banks to further improve corporate governance.

In the last three months of 2008, China cut interest rates by 216 basis points (Zhao 2009, 3). The government has improved the financial control and credit structure; strengthened monitoring and guidance of the flow of credit; increased financial support for weak links such as agriculture, rural areas, and farmers as well as small and medium-sized enterprises; and effectively resolved problems that some businesses had experienced in getting financing. It has also improved financial services, satisfied reasonable requests for financing, and created a synergy for finance to promote economic development and increase market liquidity. China has also strengthened monitoring and supervision of cross-border capital flows and maintained financial stability and security.

\section{Industrial Policy}

In changing the pattern of development, the Chinese government has continued to focus on economic restructuring and independent innovation. China is determined to turn pressure into impetus for growth, protect and develop advanced productive forces, shut down backward production facilities, integrate factors of production, and create more room for development. And it will balance its efforts to sustain economic growth, adjust economic structure, and improve economic performance to raise the overall quality of the national economy and strengthen the basis for its further development. China will continue to take deepening reform and opening up as the fundamental driving force for promoting scientific development. China needs to further emancipate its mind, intensify reform in major areas and key links, eliminate obstacles embedded in systems and mechanisms, and stimulate greater creativity for development.

In order to stabilize the overall economy, China has promulgated ten major industrial revitalization plans for 2009-2011 to support key industries and leading enterprises. The goal of the revitalization plans is not to try to promote faster growth of heavy industry, but to maintain economic and social stability — to guarantee requirements and adjust supplies. The measures to guarantee requirements are concentrated in the short and medium term to maintain stability. Measures to adjust supplies, to promote industrial upgrading and enhance international competitiveness, mainly focus on medium- and long-term industrial development.

At present, the government's investments are mainly in major projects and infrastructure construction, such as railways, highways, airports, and urban and rural water and power systems, which can directly increase the consumption of various raw materials, promote the development of related industries, and effectively ease constraints on transport, water, and electricity. These measures are intended to safeguard the 
smooth development of the economy, increase employment, and indirectly improve the people's living standards, which can enhance their purchasing power and promote production.

In order to support and promote the development of small and medium enterprises, the government has offered them more efficient and convenient credit services to help them to solve temporary production and management difficulties, encouraging enterprises to enlarge employment. At the same time, China has emphasized the development of market players and supported a shift in focus to domestic markets, especially in rural areas, so as to stimulate domestic demand. China has implemented programs for bringing home appliances, agricultural machinery, and automobiles and motorbikes to the countryside to stimulate the domestic market and enable farmers to enjoy real benefits. In 2009, 13.64 million motor vehicles were sold, an increase of 46.2 percent; housing sales amounted to 937 million square meters, up 42.1 percent; and total retail sales of consumer goods increased 16.9 percent in real terms. Consumption played a much bigger role in fueling economic growth (Wen 2010, 1). Therefore, as the financial crisis spreads to the physical economy, focusing on the expansion of domestic demand, especially consumer demand, would likely increase China's development coordination, economic competitiveness, and ability to resist risks.

\section{Social Policy}

Premier Wen Jiabao pointed out that the more difficulties that we face, the greater attention we should pay to ensuring people's well-being and promoting social harmony and stability. China continues to emphasize that maintaining and improving people's lives is always the starting point and end point of its economic work. The government has implemented an even more proactive employment policy and closely integrated efforts to stimulate growth with efforts to expand employment and improve people's lives in order to guarantee that all of the people share in the fruits of reform and development. This is extremely important not only for boosting domestic demand and stimulating growth but also for increasing the confidence and determination of the public to overcome difficulties.

Creation of employment opportunities has become one of the government's current priorities. The government not only encourages college graduates to start their own businesses, but also guides students to rural service by granting tuition compensation and compensatory student loans. The All-China Federation of Trade Unions has decided to extend aid to more than 10 million migrant workers this year, aiming to provide about 5 million migrant workers with employment assistance, such as job training and vocational instructions, and to help another 5 million safeguard their legal rights or 
offer them living assistance (Xinhua News Agency 2009b, 8). Other methods adopted by the government include the following:

- Expanding employment opportunities for rural migrant workers in cities while stabilizing their existing jobs

- Stimulating employment through government investment and the launch of major projects

- Encouraging and helping enterprises that are experiencing difficulties to prevent layoffs by renegotiating wage levels with their employees, adopting flexible employment and work hours, or providing job training

- Increasing the export of organized labor services and guiding the orderly flow of rural migrant workers

- Arranging for migrant workers who have returned to their home villages to take part in the construction of local public facilities

- Adopting and facilitating preferential policies concerning market access, taxation, financing, and land use to encourage more workers to become entrepreneurs

- Increasing policy support for skills training for rural migrant workers and urban residents who are having difficulty finding work

The government has increased expenditures on infrastructure and social security to improve people's living conditions. In 2009, the Chinese government allocated 290.6 billion RMB in social security funds. The government used 55.1 billion RMB to develop low-income housing projects, which has built, renovated or expanded 2 million low-income housing units of various types, and renovated or built 1.3 million housing units in run-down areas. The government also spent 127.7 billion RMB on medical and health care. A total of 401 million urban workers and non-working urban residents subscribed to basic medical insurance. (Wen 2010, 1 ). All these measures are likely to alleviate housing, pension, and medical difficulties and maintain social stability and development.

In addition, China has launched intensive campaigns to ensure public security and maintain law and order through a full range of measures. The government is on high alert for criminal offenses and severely cracks down on them in accordance with the law in order to safeguard national security and social stability.

\section{International Cooperation}

In the world monetary system, exchange rates are pegged to the U.S. dollar. Since the outbreak of the financial crisis, the world economy has been affected, which has become a serious obstacle to world economic development. To solve the financial cri- 
sis, international cooperation should be strengthened. Therefore, the Chinese government considers the expansion of international cooperation an important policy measure. China has participated actively in the Group of 20. China also proposes that the IMF expands its financing methods for the benefit of developing countries, so that the IMF can aid the developing countries in a timely manner when they need assistance. China is playing a crucial role in promoting the reform of IMF management mechanisms and of the international financial and monetary system, as well as strengthening the emerging countries' voice in the international financial and economic order.

As one of the BRIC (Brazil, Russia, India, and China) countries, China also attended the first BRIC summit in Russia on June 16, 2009 to strengthen international negotiations and cooperation on anti-crisis measures. At the summit, President Hu Jintao said that BRIC should strengthen the anti-crisis policy of international consultation and cooperation and push for the reform of the international financial system in order to promote world economic recovery (Xinhua News Agency 2009a, 1). A number of proposals, which have played an important constructive role in responding effectively to the financial crisis, have been adopted at the summit and by relevant international financial institutions.

Meanwhile, China, ASEAN, South Korea and Japan have actively promoted the establishment of Asian mutual funds with funds totaling US\$120 billion. China, as one of the two largest contributor countries, invested US\$38.4 billion, accounting for 32 percent of total capital. China also has signed bilateral currency swap agreements with South Korea, Malaysia, Indonesia, and other East Asian countries amounting to a total of 650 billion RMB. These agreements provide liquidity support for neighboring economies and ease the pressure of their funds shortage. In addition, China has continued to maintain large-scale imports despite its sharp decline in exports, and has even continued to expand imports from countries facing severe crisis. For example, in February and April 2009, China sent a large purchasing group to Europe and the United States, and signed US\$13 billion and US\$15 billion orders with the European Union and the United States respectively.

\section{SHORTCOMINGS OF THE CURRENT APPROACH}

Unfortunately, these policies also have obvious shortcomings, primarily in three areas. First, the long-term implementation of proactive fiscal policy can widen the fiscal deficit. A proactive fiscal policy is essentially a fiscal deficit policy. China's fiscal deficit was 58.242 billion RMB in 1997 and 259.8 billion RMB in 2001. China has projected a deficit of 1.05 trillion RMB in 2010, 100 billion RMB more than the previ- 
ous year. If the fiscal expansionary policies are continued, the budget deficit will continue to expand, and this will increase domestic financial risks.

Second, the expansionary fiscal policy has continued to strengthen administrative monopoly excluding other market competitions. At present, major infrastructure and public services are almost completely under the control of administrative monopoly. Administrative monopolies shape financial, electricity, telecommunications, railways, civil aviation, postal service, and other fields that often possess national economic resources. They are a serious obstacle to improving the market economic system. For example, in 2009, China Telecom had an income of 208.219 billion RMB and about 56.09 million mobile users. Trade monopoly can easily contribute to the expansion of the income gap. In 2009, finance and insurance industry average executive compensation both reached 11.3487 million RMB. But the per capita disposable income of urban residents was just 17,175 RMB, and the net per capita income of rural residents was 5,153 RMB (Wen 2010, 1).

Finally, the RMB exchange rate has been basically stable since the crisis started; but with the trend of the international financial situation improving and China's rapid economic rise, the pressure for RMB appreciation has become more distinct. Therefore, Chinese monetary policy faces a very complicated situation. RMB appreciation will affect Chinese exports, thereby affecting economic growth. However, exchange rate stability could lead to domestic inflation, as well as the suspicion and dissatisfaction of the international community-some of whose members, such as the United States, are likely to label China a currency manipulator.

There are three basic reasons for these negative impacts: (1) China's market economy is not perfect, and the government intervenes too much in the economy; the economy is also based mainly on public ownership, and private funds are limited, which makes it difficult for competition to emerge. (2) Chinese enterprises are mainly state owned, dependent on the government, lacking energy, and not run according to market rules. (3) The Chinese government's functions have not fully turned over, functions of government not yet separated from enterprise management completely, which has inevitably caused blind investment and duplicated construction without respecting for the market rules.

\section{CONCLUSION}

In short, the global financial crisis had a huge impact on China's economy, but it also gave China many opportunities to adjust the economic structure, increase strategic investment opportunities, and build a diversified international monetary system. 
Therefore, China needs to thoroughly evaluate how serious and complex the international and domestic economic situations are, be more mindful of potential perils and crises, fully exploit favorable conditions, and actively respond to all challenges so as to successfully promote faster economic growth.

At the same time, problems clearly exist, and the need to overcome the negative impacts of current economic policies is a major issue in the long-term development of China's economy. On one hand, the economic recovery is not yet completely stable, and the international economic situation may further decline in the future, which suggests that China should maintain the continuity of its policy, especially its proactive fiscal and monetary policies. On the other hand, these policies should be adjusted in a timely manner based on the state of the economic recovery and macroeconomic development trends. For example, the proactive fiscal policy should gradually evolve into an approach that involves more conservative fiscal and monetary policies and a focus on improving the social security system and strengthening international cooperation.

\section{REFERENCES}

Chen, X. W. 2009. Financial crisis caused 20 million unemployed migrant workers. China WTO Tribune, 68(3): 18.

Mao, X. J., and L. Yang. 2009. The challenges and countermeasures China faces to make our society stable under the financial crisis. Journal of Jiangxi Public Security College, 131(3): 5-8.

Ru, X., X. Lu, and P. Li. 2008. The Blue-Cover Book of the Chinese Society 2009: Society of China: Analysis and forecast 2009. Beijing: Social Sciences Academic Press (China).

State Administration of Foreign Exchange. 2009. Monthly foreign exchange reserves, 2009. http://www.safe.gov.cn/model_safe_en/tjsj_en/tjsj_detail_en.jsp?ID= $30303000000000000,18 \& i d=4$.

Wen, J. B. 2009a. See China in the light of her development. Speech at the University of Cambridge, reproduced in Renmin Ribao, February 4.

. 2009b. Premier Wen Jiabao to answer journalists questions. Renmin Ribao, March 14.

2010. Report on the work of the government. Renmin Ribao, March 16.

Wu, J. L. 2009. The financial tsunami and China's economy. Journal of Shanghai University (Social Sciences), 16(1): 5-13.

Xinhua News Agency. 2009a. BRIC summit was held in Yekaterinburg. Renmin Ribao, June 17. 
. 2009b. China trade unions aim to aid 10 million migrant workers. Renmin Ribao, February 18.

2009c. Employment of university students: Difficulties? Renmin Ribao, July 7.

. 2010. Report on national economic and social development of China for 2009. Renmin Ribao, March 17.

Zhao, Y. W. 2009. CPI falls in line with expectations. International Finance News, February 11. 